\title{
Antibiotic additive and synergistic action of rutin, morin and quercetin against methicillin resistant Staphylococcus aureus
}

\author{
Muhammad Usman Amin ${ }^{1 \dagger}$, Muhammad Khurram² ${ }^{*+}$, Baharullah Khattak ${ }^{1 \dagger}$ and Jafar Khan ${ }^{1 \dagger}$
}

\begin{abstract}
Background: To determine the effect of flavonoids in conjunction with antibiotics in methicillin resistant Staphylococcus aureus (MRSA) a study was designed. The flavonoids included Rutin, Morin, Qurecetin while antibiotics included ampicillin, amoxicillin, cefixime, ceftriaxone, vancomycin, methicillin, cephradine, erythromycin, imipenem, sulphamethoxazole/trimethoprim, ciprofloxacin and levolfloxacin. Test antibiotics were mostly found resistant with only Imipenem and Erythromycin found to be sensitive against 100 MRSA clinical isolates and S. aureus (ATCC 43300). The flavonoids were tested alone and also in different combinations with selected antibiotics.
\end{abstract}

Methods: Antibiotics and flavonoids sensitivity assays were carried using disk diffusion method. The combinations found to be effective were sifted through MIC assays by broth macro dilution method. Exact MICs were determined using an incremental increase approach. Fractional inhibitory concentration indices (FICl) were determined to evaluate relationship between antibiotics and flavonoids is synergistic or additive. Potassium release was measured to determine the effect of antibiotic-flavonoids combinations on the cytoplasmic membrane of test bacteria.

Results: Antibiotic and flavonoids screening assays indicated activity of flavanoids against test bacteria. The inhibitory zones increased when test flavonoids were combined with antibiotics facing resistance. MICs of test antibiotics and flavonoids reduced when they were combined. Quercetin was the most effective flavonoid (MIC $260 \mu \mathrm{g} / \mathrm{ml}$ ) while morin + rutin + quercetin combination proved most efficient with MIC of $280+280+140 \mu \mathrm{g} / \mathrm{ml}$. Quercetin + morin + rutin with amoxicillin, ampicillin, cephradine, ceftriaxone, imipenem, and methicillin showed synergism, while additive relationship was indicated between morin + rutin and amoxicillin, cephradine, ceftriaxone, imipenem, and methicillin. Quercetin alone had an additive effect with ampicillin, cephradine, ceftriaxone, imipenem, and methicillin. Potassium leakage was highest for morin + rutin + quercetin that improved further in combination with imipenem. Morin and rutin alone had no activity but in combination showed activity against test bacteria.

Conclusions: The flavonoids when used in combination with antibiotics were found to increase each other activity against test bacteria. The relationship between the flavonoids and antibiotics in most of the cases was additive. However in a few cases synergism was also observed. Flavonoids alone or in combinations also damaged bacterial cell membrane.

Keywords: Morin, Rutin, Quercetin, MRSA

\footnotetext{
* Correspondence: pharmacistkhurram@hotmail.com

${ }^{\dagger}$ Equal contributors

2Department of Pharmacy, Shaheed Benazir Bhutto University, Sheringal, Dir Upper, KP, Pakistan

Full list of author information is available at the end of the article
}

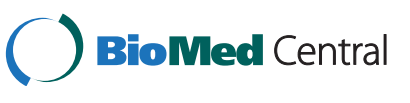

(c) 2015 Amin et al.; licensee BioMed Central. This is an Open Access article distributed under the terms of the Creative Commons Attribution License (http://creativecommons.org/licenses/by/4.0), which permits unrestricted use, distribution, and reproduction in any medium, provided the original work is properly credited. The Creative Commons Public Domain Dedication waiver (http://creativecommons.org/publicdomain/zero/1.0/) applies to the data made available in this article unless otherwise stated. 


\section{Background}

Plant secondary metabolites are characteristic of certain plant species that occur as part of their normal metabolism with little or no function in plant life cycle. These metabolites may have bioactivities and also medicinal value like anti-infective, antitumor, antithrombotic, and antihyperlipidemic [1]. Different species of genus Cipadessa, are used in mitigation of rheumatism, malaria, dysentery, diabetes, and haemorrhoids and as anti-venom in snake bites, with active constituents including flavonoids, terpenoids, tetranortriterpenoids, steroids and sesqueterpenoids [2]. This is indicative that these metabolites may be a common feature among different species of a genus, showing common pharmacological effects in different ailments. About 400 species of Saussurea genus, are used as traditional medicines in China and Tibet in problems related to menstruation, blood circulation, fever and rheumatoid arthritis. The reason for their use in these conditions is due to the presence of biologically active compounds including flavonoids, terpenoids, phytosterols, and phenolics. The antimicrobial activities in these plant species have been related to flavanoids, terpenoids and tannins [3]. Flavonoids are generally present in photosynthesizing cells [4]. From ancient times, preparations containing these compounds have been used to treat human diseases. This class of natural products is becoming the main target of research due to their antimicrobial potentials.

Flavonoids have good antibacterial activities, like chrysin that showed bacteriostatic activity against different Gramnegative bacteria such as Escherichia coli and Pseudomonas aeruginosa. Similarly, biacalien possess inhibitory effect on $S$. aureus and on the growth of spore forming Bacillus subtilis. Other flavonoids such as luteolin, lucenin, apigenin, saponarin and vitexin were effective against Gram-negative bacteria Enterobacter cloacae, Klebsiella pneumonia, Proteus mirabilis, E. coli, P. aeruginosa, and Proteus vulgaris [5]. An 126 interesting feature of these flavonoids is their potentiating and synergistic behaviour that is observed between active flavonoids as well as combination of flavonoids with antimicrobial agents [6]. Flavonoids like myricetin, datiscetin, kaempferol, qurecetin and flavones like luteolin have inhibited growth of MRSA and with myricetin were found effective against VRE as well [7]. In another study alkyl gallates (methyl, ethyl, propyl and butyl gallates) and gallic acid with different classes of antibiotics such as $\beta$-lactams (penicillin G, ampicillin, oxacillin, cephradine), quinolone (norfloxacin), aminoglycosides (streptomycin, kanamycin, vancomycin), chloramphenicol, arbekacin, fosfomycin and tetracycline were used in combinations against drug sensitive and resistant bacteria. It was observed that these combinations had maximum inhibitory activity in $90 \%$ clinical isolates at MIC of $15.6 \mu \mathrm{g} / \mathrm{ml}$. However, combinations of $\beta$-lactams and alkyl gallates showed synergestic activities against MRSA and MSSA [8].

Resistance to antimicrobial agents is a global issue with methicillin resistant Staphylococcus aureus (MRSA) a major concern [9]. In a study conducted in Pakistan during 2005-2007, about 501 MRSA clinical isolates were isolated from skin and soft tissue infections and were tested for their susceptibilities against conventional antibiotics such as clindamycin, tetracyclines, cotrimoxazole and rifampicin, chloramphenicol and fusidic acid. All of these drugs were ineffective against MRSA isolates [10].

Difficulties in treatment of resistant microbes serve a challenge to discover new drugs that can be effective against these resistant bugs. Since plant metabolites are not part of conventional therapy they can be considered as monotherapy or in combination therapy against them. Keeping in view the emerging threat of MRSA, present study was designed to evaluate impact of selected flavonoids (morin, rutin, quercetin) alone and in combination with conventionally used antibiotics for their activities against S. aureus (ATCC 43300) and 100 MRSA clinical isolates.

\section{Methods}

\section{Materials}

The antibiotic discs included amoxicillin (AMO; $25 \mu \mathrm{g}$ ), ampicillin (AMP; $10 \mu \mathrm{g}$ ), ceftriaxone (CET; $30 \mu \mathrm{g}$ ), cefixime (CEF; $5 \mu \mathrm{g})$, cephradine (CEPH; $30 \mu \mathrm{g}$ ), erythromycin (ERY; $15 \mu \mathrm{g}$ ), vancomycin (VAN; $30 \mu \mathrm{g}$ ), methicillin (ME; $10 \mu \mathrm{g}$ ), ciprofloxacin (CIP; $5 \mu \mathrm{g}$ ), levolfloxacin (LEV; $5 \mu \mathrm{g})$, sulfamethaxozole-trimethoprim (S-T; $25 \mu \mathrm{g}$ ) and imipenem (IMP; $10 \mu \mathrm{g}$ ) were from Oxoid, UK while blank discs were purchased from Himedia, India. Test flavonoids; rutin, morin, and quercetin were purchased from Sigma-Aldrich, UK. Stock solutions of flavonoids morin, rutin, and quercetin were made at concentrations of $50 \mathrm{~g} / \mathrm{l}, 6 \mathrm{~g} / \mathrm{l}$, and $10 \mathrm{~g} / \mathrm{l}$ respectively, using ethanol. Bacterial culturing medias such as nutrient agar (NA; CM0003B), muller hinton agar (MHA; CM0337B), nutrient broth (N.B; CM0001B) and muller hinton broth (MHB; CM0405B) were from Oxoid, UK. mannitol salt agar (MSA; LAB007) was obtained from Lab M Limited, UK.

\section{Bacterial cultures collection, transport and processing}

Clinical isolates $(n=300)$ were obtained from the microbiology laboratories of tertiary care hospitals which are Hayatabad Medical complex, Lady Reading Hospital and Khyber Teaching Hospital of Peshawar, KPK, Pakistan while S. aureus (ATCC 43300, Rockville, USA) present at PCSIR laboratories, was used as standard. Clinical isolates were transported to Microbiology lab, PCSIR Peshawar, Pakistan, for culturing, the same day within 2 hours after collection. 
Clinical isolates were sub-cultured on sterile nutrient agar (NA) plates and then incubated at $37 \pm 1^{\circ} \mathrm{C}$ for 18 - 20 hours. Following incubation, plates showing growth were subjected to Gram staining, catalase test, coagulase test [11], and mannitol salt agar differentiation [12]. The organisms showing yellow colonies on MSA plates, gram-positive cocci in clusters, coagulase + ve, and catalase + ve were considered S. aureus.

Isolated colonies of $S$. aureus from MSA plates were aseptically inoculated in sterile nutrient broth and incubated overnight at $37^{\circ} \mathrm{C}$. Thereafter, turbidity of inoculum was adjusted to 0.5 McFarland using $0.9 \%(\mathrm{w} / \mathrm{v})$ sterile normal saline and was used to prepare bacterial lawns on sterile MHA plates. Methicillin discs were applied on seeded plates and incubated overnight at $37 \pm 1^{\circ} \mathrm{C}$. Following incubation, plates with zones of inhibitions $<10 \mathrm{~mm}$ diameter or no zone of inhibition were considered to be MRSA. The study was approved by the Ethical Review Committee of Kohat University of Science and Technology with a waiver of informed consent.

\section{Antibiotic sensitivity assays}

Susceptibilities of clinical isolates and ATCC 43300 against selected antibiotics, flavonoids and antibiotic + flavonoids combinations were found using disc diffusion assay [13]. Flavonoids were tested alone, in different combinations, and with test antibiotics at different concentrations as shown in Table 1. Susceptibilities assays were carried using sterile MHA plates. Following overnight incubation at $37^{\circ} \mathrm{C}$ zones of inhibitions were recorded. Test substances were considered to have activity if zone of inhibition was $>10 \mathrm{~mm}$, while $\leq 10 \mathrm{~mm}$ zone of inhibition were regarded as inactive.

\section{Minimum inhibitory concentration (MIC) assays}

MIC assays were carried out using broth macro-dilution method. Different concentrations of flavonoids, their combinations alone and with antibiotics were used. Flavonoids and their combinations included morin + rutin $(\mathrm{M}+\mathrm{R})$, quercetin $(\mathrm{Q})$ and morin + rutin + quercetin $(\mathrm{M}+\mathrm{R}+\mathrm{Q})$. Test antibiotics with flavonoids alone and their combinations included amoxicillin, ampicillin, ceftriaxone, cephradine, imipenem and methicillin. Test concentrations of flavonoids, flavonoid combinations alone and with antibiotics are given in Table 2. The MICs of these antibiotics against MRSA alone and in combination

Table 1 Flavonoids used in antibiotic sensitivity assays

\begin{tabular}{ll}
\hline Flavonoids & Test concentrations used \\
\hline Morin (M) & $100 \mu \mathrm{g}, 200 \mu \mathrm{g}, 300 \mu \mathrm{g}, 400 \mu \mathrm{g}, 500 \mu \mathrm{g}$ \\
Rutin (R) & $100 \mu \mathrm{g}, 200 \mu \mathrm{g}, 300 \mu \mathrm{g}, 400 \mu \mathrm{g}, 500 \mu \mathrm{g}$ \\
Quercetin (Q) & $100 \mu \mathrm{g}, 200 \mu \mathrm{g}, 300 \mu \mathrm{g}$ \\
\hline
\end{tabular}

with flavonoids were determined to confirm the synergistic or additive effects. For the MIC's assays stock solutions of these antibiotics were prepared using sterile distilled water.

Exact MIC's of flavonoids alone, in combinations and with test antibiotics were determined by an incremental increase approach in which higher concentrations were obtained by the addition of $20 \mu \mathrm{g}$ increments to the lower concentrations. After test materials were transferred into sterile test tubes, bacterial cultures were prepared as mentioned earlier. After inoculation and addition of test materials tubes were incubated overnight at $37^{\circ} \mathrm{C}$. Absence of any visible growth in test tubes was considered as the MIC of test material.

\section{Fractional Inhibitory concentration (FIC) \& FIC Index}

To determine the effectiveness of test substances for synergistic, antagonistic or additive effects FIC indices were measured, using following formulas [14].

FIC of antibiotic $\left(\mathrm{FIC}_{\text {antibiotic }}\right)=\mathrm{MIC}$ of antibiotic in combination / MIC of antibiotic alone

$\mathrm{FIC}$ of flavonoid $\left(\mathrm{FIC}_{\text {flavonoid }}\right)=\mathrm{MIC}$ of flavonoid in combination / MIC of flavonoid alone

While FIC index was the sum of FIC of both antibiotic and flavonoid.

$\mathrm{FIC}$ Index $(\mathrm{FICI})=\mathrm{FIC}_{\text {antibiotic }}+\mathrm{FIC}_{\text {flavonoid }}$

In case of two or more flavonoids used in combination FIC was calculated in accordance to following formula [15].

$$
\mathrm{FIC}=(\mathrm{A} / \mathrm{Ma})+(\mathrm{B} / \mathrm{Mb})
$$

Where A and B are the MIC's of these compounds in combination while $\mathrm{Ma}$ and $\mathrm{Mb}$ are individual MICs of test compounds. The test materials in their combinations alone or with standard antibiotics were graded to have synergistic $(\leq 0.5)$, additive ( $>0.5$ to 1$)$, indifferent $(>1$ to $<2)$ or antagonistic $(\geq 2)$ on the basis of FIC indices [16].

\section{Detection of cytoplasmic membrane damage}

The assessment of the potassium present in medium was carried out using flame photometer (PFP7, Jenway, Sweden) at wavelength of $766.480 \mathrm{~nm}$. Instrument was calibrated using standard solutions containing 0.05, 0.1, $0.5,1.0$ and $5.0 \mu \mathrm{g} / \mathrm{ml}$ potassium chloride in ultra-pure deionised water obtained from $\mathrm{HACH}$ water system USA.

Aliquots of $100 \mu \mathrm{l}$ from each MRSA clinical isolate and $S$. aureus (ATCC 43330) were separately incubated overnight after incorporation of $1 \mathrm{ml}$ previously sterilized nutrient broth. The rise in the amount of potassium in supernatant, caused by antibiotics, flavonoids, flavonoidsantibiotics combination, in clinical isolates and control 
Table 2 Test concentrations of flavonoids and their combination for MIC assays

\begin{tabular}{|c|c|c|c|c|}
\hline \multirow[t]{3}{*}{ Flavonoids } & \multicolumn{4}{|c|}{ Concentration ranges used for MIC assays (in $\mu \mathrm{g} / \mathrm{ml}$ ) } \\
\hline & \multicolumn{2}{|c|}{ Broth half dilution method } & \multicolumn{2}{|c|}{ Incremental increase approach $†$} \\
\hline & Maximum & Minimum & Maximum & Minimum \\
\hline Morin (M) & $N T^{*}$ & NT & NT & NT \\
\hline Rutin(R) & NT & NT & NT & NT \\
\hline Quercetin(Q) & 600 & 75 & 300 & 180 \\
\hline Morin + Rutin $(M+R)$ & $800+800$ & $100+100$ & $500+500$ & $380+380$ \\
\hline Morin + Rutin + Quercetin $(M+R+Q)$ & $600+600+400$ & $150+150+100$ & $400+400+260$ & $260+260+120$ \\
\hline
\end{tabular}

† To determine Exact MIC's of test substances an incremental increase approach was adopted with $20 \mu \mathrm{g}$ decrease in each dilution. ${ }^{*}$ Not tested.

strain was measured following separation of cellular debris by centrifugation at $4000 \mathrm{rpm}$.

\section{Results}

\section{Antibiotic sensitivity assays}

Quercetin, $M+R$, and $M+Q+R$ showed some activities against MRSA clinical isolates and ATCC 43300. However, morin, rutin and $Q+R, Q+M$ combinations were found inactive against test bacteria (Table 3). Quercetin and active combinations were found to be more effective when the antibiotics were combined with them. Antibiotics like AMO, AMP, CEPH, CET, ME, S-T, and CEF that were inactive when tested alone, expressed activity when combined with $\mathrm{Q}, \mathrm{M}+\mathrm{R}$ and $\mathrm{M}+\mathrm{R}+\mathrm{Q}$ (Table 4). However, test flavonoids were found to be having no impact on VAN and ERY activity, while causing reduction in CIP and LEV activities.

The concentration at which $M+R$ showed activity against the bacteria under study was $500 \mu \mathrm{g}$ for each of the flavonoid. The inhibition zones of this combination observed at this concentration were $11.5 \pm 0.22 \mathrm{~mm}$ against standard bacteria and $11.58 \pm 0.21 \mathrm{~mm}$ against 100 clinical isolates. Moreover, $\mathrm{M}+\mathrm{R}$ was found to increase activity of AMO, CEPH, IMP, CET and ME. CET activity was increased highest, from 0 to $16.5 \pm 0.30 \mathrm{~mm}$

\begin{tabular}{|c|c|c|}
\hline $\begin{array}{l}\text { Test flavonoid or } \\
\text { flavonoids combination }\end{array}$ & S. aureus & $\begin{array}{l}\text { MRSA clinical } \\
\text { isolates }(n=100)\end{array}$ \\
\hline M & 0 & 0 \\
\hline R & 0 & 0 \\
\hline Q & $13.5 \pm 0.21$ & $13.33 \pm 0.26$ \\
\hline$M+R$ & $11.5 \pm 0.22$ & $11.58 \pm 0.21$ \\
\hline$Q+R$ & 0 & 0 \\
\hline$Q+M$ & 0 & 0 \\
\hline$M+Q+R$ & $16.5 \pm 0.21$ & $16.23 \pm 0.26$ \\
\hline
\end{tabular}

against standard and the zone of inhibition was increased from 0 to $16.5 \pm 0.29 \mathrm{~mm}$, in comparison to all other test antibiotics finding resistance against both standard strain and clinical isolates. The zone of inhibition of vancomycin and erythromycin were $18 \pm 0.59 \mathrm{~mm}$ and $22 \pm 1.36 \mathrm{~mm}$ against ATCC 43300, which remained same in combination with $\mathrm{M}+\mathrm{R}$. However, IMP activity enhanced from $16 \pm 0.90 \mathrm{~mm}$ to $19.5 \pm 0.58 \mathrm{~mm}$ against ATCC 43300, while for clinical isolates it became $19.62 \pm 0.31 \mathrm{~mm}$ from $16.18 \pm 0.92 \mathrm{~mm}$ in combination with $\mathrm{M}+\mathrm{R}$. The $\mathrm{S}-\mathrm{T}$ and AMP had no activity against test bacteria alone as well as in combination with flavonoids. Ethanol, which was used in making solutions of flavonoids, was having no inhibitory activity.

Quercetin was found to be more active than $M+R$ combination. The average zones of inhibition of quercetin against MRSA clinical isolates were $13.33 \pm 0.26 \mathrm{~mm}$ while it was $13.5 \pm 0.21 \mathrm{~mm}$ in case of ATCC 43300 . The results revealed that quercetin alone possessed antibacterial activity while morin and rutin have the same activity when they were used in combination. It was also found to increase the activity of antibiotics AMP, CEPH, CET and ME that experienced resistance. Quercetin also had a more blunting effect for CIP and LEV in comparison to $M+R$. It is evident from data presented in Table 4 that among the antibiotics facing resistance, CET was most responsive in combination with quercetin as zones of inhibition enhanced from 0 to $20.5 \pm 0.5 \mathrm{~mm}$ against ATCC 43300 and $20.83 \pm 0.45 \mathrm{~mm}$ in case of clinical isolates, respectively. IMP was active against test MRSA and its activity was further improved by quercetin from $16 \pm 0.90 \mathrm{~mm}$ to $22 \pm 1.10 \mathrm{~mm}$ against ATCC 43300 while in case of clinical isolates it increased from $16.18 \pm 0.92 \mathrm{~mm}$ to $22.18 \pm 1.12 \mathrm{~mm}$. ERY and VAN activities remained unchanged and resistance for S-T persisted even when it was combined with quercetin.

As quercetin and $M+R$ were found to have activities against MRSA, they were combined together, and tested in flavonoids combination as well as flavonoids-antibiotic combinations against test bacteria. The results in the Table 4 show that combined effect of flavonoids is greater 
Table 4 Average zone of inhibitions (in $\mathrm{mm} \pm$ STDEV) of antibiotics alone and with flavonoid/(s) against S. aureus (ATCC 43300) and MRSA clinical isolates $(n=100)$

\begin{tabular}{|c|c|c|c|c|}
\hline & Antibiotic alone & $M+R$ with antibiotic & Q with antibiotic & $M+R+Q$ with antibiotic \\
\hline AMO † & 0 & $14.5 \pm 0.29$ & $13.5 \pm 0.21$ & $23.50 \pm 1.1$ \\
\hline $\mathrm{AMO} *$ & 0 & $14.18 \pm 0.36$ & $13.33 \pm 0.26$ & $23.73 \pm 1.1$ \\
\hline AMP + & 0 & $11.5 \pm 0.22$ & $17 \pm 0.29$ & $22.5 \pm 1.2$ \\
\hline $\mathrm{AMP} *$ & 0 & $11.58 \pm 0.21$ & $17.33 \pm 0.30$ & $22.63 \pm 1.2$ \\
\hline CEPH† & 0 & $14.5 \pm 0.32$ & $18.5 \pm 0.31$ & $24.55 \pm 1.00$ \\
\hline $\mathrm{CEPH}^{*}$ & 0 & $14.18 \pm 0.29$ & $18.33 \pm 0.30$ & $24.22 \pm 1.00$ \\
\hline CET + & 0 & $16.5 \pm 0.30$ & $20.5 \pm 1.00$ & $27 \pm 1.20$ \\
\hline $\mathrm{CET}^{*}$ & 0 & $16.18 \pm 0.29$ & $20.83 \pm 1.00$ & $27.24 \pm 1.23$ \\
\hline IMP † & $16 \pm 0.90$ & $19.5 \pm 0.58$ & $22 \pm 1.10$ & $28 \pm 1.00$ \\
\hline IMP* & $16.18 \pm 0.92$ & $19.62 \pm 0.31$ & $22.18 \pm 1.12$ & $28.21 \pm 0.90$ \\
\hline ME $†$ & 0 & $13.5 \pm 0.31$ & $16.5 \pm 0.28$ & $21.5 \pm 1.1$ \\
\hline$M E^{*}$ & 0 & $13.18 \pm 39$ & $16.89 \pm 0.29$ & $21.73 \pm 1.0$ \\
\hline VAN † & $18 \pm 0.59$ & $18 \pm 0.59$ & $18 \pm 0.59$ & $18 \pm 0.59$ \\
\hline VAN* & $17.37 \pm 0.80$ & $17.37 \pm 0.80$ & $17.37 \pm 0.80$ & $17.37 \pm 0.80$ \\
\hline LEV † & $14 \pm 0.91$ & $9 \pm 0.25$ & $6.5 \pm 0.21$ & $3 \pm 0.24$ \\
\hline $\mathrm{LEV}^{*}$ & $13.88 \pm 1.21$ & $9.52 \pm 0.25$ & $6.85 \pm 0.22$ & $3.23 \pm 0 . .25$ \\
\hline CIPt & $10.5 \pm 2.5$ & $7.24 \pm 0.19$ & $4 \pm 0.22$ & $2.25 \pm 0.24$ \\
\hline $\mathrm{ClP}^{*}$ & $13.1 \pm 3.1$ & $8.1 \pm 0.18$ & $4.35 \pm 0.24$ & $2.73 \pm 0.21$ \\
\hline ERY † & $22 \pm 1.36$ & $22 \pm 1.36$ & $22 \pm 1.36$ & $22 \pm 1.36$ \\
\hline$E R Y^{*}$ & $20.96 \pm 2.1$ & $20.96 \pm 1.10$ & $20.96 \pm 1.10$ & $20.96 \pm 1.1$ \\
\hline S-T † & 0 & $11.5 \pm 0.22$ & $13 \pm 0.21$ & $14 \pm 0.21$ \\
\hline$S-T^{*}$ & 0 & $11.58 \pm 0.21$ & $13.33 \pm 0.26$ & $14.23 \pm 0.26$ \\
\hline CEF + & 0 & $11.5 \pm 0.22$ & $13 \pm 0.21$ & $14 \pm 0.21$ \\
\hline $\mathrm{CEF}^{*}$ & 0 & $11.58 \pm 0.21$ & $13.33 \pm 0.26$ & $14.23 \pm 0.26$ \\
\hline
\end{tabular}

† activity against S. aureus (ATCC 43300).

*activity against clinical isolates.

than their individual effects, zones of inhibition of these flavonoids $(M+R+Q)$ against ATCC 43300 were $16.5 \pm 0.21 \mathrm{~mm}$ and for clinical isolates $16.23 \pm 0.26 \mathrm{~mm}$, which are greater than that of $\mathrm{M}+\mathrm{R}(11.5 \pm 0.22 \mathrm{~mm}$ for ATCC $43300 \& 11.58 \pm 0.21 \mathrm{~mm}$ against clinical isolates) and quercetin $(13.33 \pm 0.21 \mathrm{~mm} \& 13.5 \pm 0.26 \mathrm{~mm})$ respectively. It is evident from the results in Table 4 that with triplet combination $(\mathrm{M}+\mathrm{R}+\mathrm{Q})$ the activity of both $\mathrm{AMP}$ and AMO were increased. The inhibitory zones observed in case of AMP and AMO with $\mathrm{M}+\mathrm{R}+\mathrm{Q}$ were $22.5 \pm 1.2 \mathrm{~mm} \& 23.50 \pm 1.1 \mathrm{~mm}$ against ATCC 43300 . While against clinical isolates zone of inhibition of AMO in combination with $\mathrm{M}+\mathrm{R}+\mathrm{Q}$ was $23.73 \pm 1.1 \mathrm{~mm}$ which was greater than that observed for AMO against the clinical isolates in combination with $M+R$ $(14.18 \pm 0.36 \mathrm{~mm})$ and $\mathrm{Q}(13.33 \pm 0.26 \mathrm{~mm})$. Same trend was also observed in case of AMP in combination with $\mathrm{M}+\mathrm{R}+\mathrm{Q}$, where inhibitory zones against the clinical isolates were $22.63 \pm 1.2 \mathrm{~mm}$ which were greater than that observed for AMP when combined with $M+R$ and $Q \cdot M+R+Q$ showed no effect on the activity of VAN and ERY as the zones of inhibition remained same. The antagonistic effect of $M+R+Q$ on CIP and LEV was greater than that observed with $\mathrm{M}+\mathrm{R}$ and $\mathrm{Q}$ alone. $M+R+Q$ had no effect on the activities of S-T and CEF.

\section{MICs by serial half dilution method}

Test flavonoids in combination or alone were quantified for activities using serial broth half dilution method (Table 5). The results for clinical isolates showed variation with 14 isolates giving MIC of $400+400 \mu \mathrm{g} / \mathrm{ml}$ for $\mathrm{M}+\mathrm{R}$ while rest of isolates $(n=86)$ were inhibited at $800+800 \mu \mathrm{g} / \mathrm{ml}$ concentrations. Similarly, for $M+R+Q, 60$ isolates gave MIC of $200+300+300 \mu \mathrm{g} / \mathrm{ml}$ while remaining isolates $(n=40)$ were inhibited at $200+600+600 \mu \mathrm{g} / \mathrm{ml}$ concentrations. The MIC of quercetin determined by serial half dilution method against the MRSA 43300 was $300 \mu \mathrm{g} / \mathrm{ml}$ and same MIC was observed against 64 MRSA clinical isolates shown in Table 5. While against remaining clinical isolates $\mathrm{n}=36$, the MIC of quercetin was $600 \mu \mathrm{g} / \mathrm{ml}$. 
Table 5 MICs of flavonoid/(s) against S. aureus (ATCC 43300) and clinical isolates of MRSA

\begin{tabular}{lll}
\hline Flavonoids & TMIC $(\boldsymbol{\mu g} / \mathbf{m l})$ & ${ }^{*}$ MIC $(\boldsymbol{\mu g} / \mathbf{m l})$ \\
\hline$M+R$ & $400+400$ & $400+400(n=14)$ \\
& & $800+800(n=86)$ \\
Q & 300 & $300(n=64)$ \\
& & $600(n=36)$ \\
$M+R+Q$ & $200+300+300$ & $200+300+300(n=60)$ \\
& & $200+600+600(n=40)$ \\
\hline
\end{tabular}

$\dagger$ activity against S. aureus (ATCC 43300).

*activity against clinical isolates.

\section{Exact MICs of flavonoids and flavonoids-antibiotics by incremental increase approach}

Exact MICs of $\mathrm{M}+\mathrm{R}$, quercetin and $\mathrm{M}+\mathrm{R}+\mathrm{Q}$ alone and in combination with antibiotics were determined against MRSA clinical isolates and ATCC 43300. The MIC of $M+R$ first determined by half dilution method is given in Table 5 . It is evident that MIC of each flavonoid in combination was $400 \mu \mathrm{g} / \mathrm{ml}$ against standard strain ATCC 43330. However, in case of clinical isolates MIC of 14 strains was $400 \mu \mathrm{g} / \mathrm{ml}$ while rest of 86 isolates gave $\mathrm{MIC}$ value of $800 \mu \mathrm{g} / \mathrm{ml}$. In order to arrive at exact MIC for these strains an incremental increase approach was adopted. The MIC data from this method is presented in Table 6 for flavonoid and their combinations while Table 7 gives exact MICs of flavonoids in combination with test antibiotics.

Exact $\mathrm{MIC}$ for $\mathrm{M}+\mathrm{R}$ was $400 \mu \mathrm{g} / \mathrm{ml}$ against ATCC 43300 while for clinical isolates $(n=100)$ average MIC was $427.40 \pm 14.40 \mu \mathrm{g} / \mathrm{ml}$ (Table 6). When combined with amoxicillin (AMO) the MIC of $\mathrm{M}+\mathrm{R}$ decreased to $340 \mu \mathrm{g} / \mathrm{ml}$ against ATCC 43300. This indicated that there may be synergism or additive relationship between the flavonoids and antibiotics experiencing resistance. Similarly average MIC of M $+\mathrm{R}(427.40 \pm 14.40 \mu \mathrm{g} / \mathrm{ml})$ was reduced to $367.40 \pm 15.71 \mu \mathrm{g} / \mathrm{ml}$ when combined with AMO. In case of CET the MIC of $M+R$ against ATCC 43300 was found to reduce from $400 \mu \mathrm{g} / \mathrm{ml}$ to $320 \mu \mathrm{g} / \mathrm{ml}$ while against the clinical isolates it decreased from $427.40 \pm 14.40 \mu \mathrm{g} / \mathrm{ml}$ to $347.40 \pm 12.92 \mu \mathrm{g} / \mathrm{ml}$. Similar trend was also observed in case of other antibiotics. A difference in the MIC's of $M+R$ and $M+R+$ antibiotic can be seen in Tables 6 \& 7. It is evident that reduction in MICs of $\mathrm{M}+\mathrm{R}$ is greater with IMP as it dropped from $400 \mu \mathrm{g} / \mathrm{ml}$ to $300 \mu \mathrm{g} / \mathrm{ml}$ followed by CET, AMO and CEPH with MICs reducing to $320 \mu \mathrm{g} / \mathrm{ml}, 340 \mu \mathrm{g} / \mathrm{ml}$ and $340 \mu \mathrm{g} / \mathrm{ml}$ respectively against ATCC 43300. Same trend was also observed with these antibiotics when tested against clinical isolates. Methicillin was found to be less responsive than other antibiotics. The reduction in MIC of flavonoids when combined with antibiotics was an indication of their increased activity against the bacteria under study.
The MIC of quercetin determined by serial half dilution method against ATCC 43300 was $300 \mu \mathrm{g} / \mathrm{ml}$ and similar MIC was observed against 64 MRSA clinical isolates (Table 6), while remaining clinical isolates $(n=36)$ were inhibited at $600 \mu \mathrm{g} / \mathrm{ml}$. Exact MIC of quercetin came to be $260 \mu \mathrm{g} / \mathrm{ml}$ for ATCC 43300 and for clinical isolates $(\mathrm{n}=100)$ it varied between $260-300 \mu \mathrm{g} / \mathrm{ml}$. Reduction in MIC of quercetin in combination with antibiotics was observed (Table 7) as it dropped from $260 \mu \mathrm{g} / \mathrm{ml}$ to $160 \mu \mathrm{g} / \mathrm{ml}$ when combined with AMP in case of MRSA 43300 whilst average MIC against clinical isolates reduced from $284.64 \pm 19.31 \mu \mathrm{g} / \mathrm{ml}$ to $184.64 \pm 16.25 \mu \mathrm{g} / \mathrm{ml}$. Average MIC of Q with $\mathrm{CEPH}$ against clinical isolates reduced to the same extent as for AMP. For ME the decrease in the MIC was less than the other antibiotics.

Combinations of $\mathrm{M}+\mathrm{R}+\mathrm{Q}$ were tested to determine the effectiveness against test bacteria. A clear reduction in MICs was evident in comparison to their individual MICs. The MIC of $\mathrm{M}+\mathrm{R}+\mathrm{Q}$ came to $300+300+200 \mu \mathrm{g} / \mathrm{ml}$ for sixty clinical isolates while it was $600+600+200 \mu \mathrm{g} / \mathrm{ml}$ for rest of forty isolates. Exact MIC of $M+R+Q$ was also determined (Table 6). It was observed that exact MIC of $\mathrm{Q}$ in combination was $140 \mu \mathrm{g} / \mathrm{ml}$ and that of $\mathrm{M}+\mathrm{R}$ was $280+280 \mu \mathrm{g} / \mathrm{ml}$ against ATCC 43300 whilst in case of clinical isolates $(n=100) Q$ had average MIC $163.56 \pm 15.23 \mu \mathrm{g} / \mathrm{ml}$ while $\mathrm{M}+\mathrm{R}$ had (303.56 \pm $16.74 \mu \mathrm{g} / \mathrm{ml})+(303.56 \pm 16.74 \mu \mathrm{g} / \mathrm{ml})$. It is evident from data that in case of $M+R+Q$ MICs of not only rutin-morin reduced but quercetin's MIC dropped as well. The MIC of rutin-morin each was $400 \mu \mathrm{g} / \mathrm{ml}$ but along with qurecetin it fell to $280 \mu \mathrm{g} / \mathrm{ml}$ against ATCC 43300 whilst that of qurecetin reduced from $260 \mu \mathrm{g} / \mathrm{ml}$ to $140 \mu \mathrm{g} / \mathrm{ml}$. Thus the antibacterial activity of flavonoids was found to increase against MRSA when used in combination with each other. Similarly the incorporation of antibiotics with $M+R+Q$ had an enhancing effect on activities of test antibiotics. Data in Table 7 suggests that MIC of this combination was further reduced when combined with test antibiotics, i.e., with AMO, the MIC of rutin-morin and quercetin was further reduced to $140 \mu \mathrm{g} / \mathrm{ml}$ (each) and $80 \mu \mathrm{g} / \mathrm{ml}$ against ATCC 43300. The average MIC of rutin-morin with AMO against the MRSA clinical isolates reduced to $163.56 \pm 16.75 \mu \mathrm{g} / \mathrm{ml}$ from $367.40 \pm 15.71 \mu \mathrm{g} / \mathrm{ml}$ but quercetin had no effect on AMO activity. However in $\mathrm{M}+\mathrm{R}+\mathrm{Q}$ with $\mathrm{AMO}$, quercetin activity was increased as its average MIC decreased to $103.56 \pm 15.99 \mu \mathrm{g} / \mathrm{ml}$ from $284.64 \pm 19.31 \mu \mathrm{g} / \mathrm{ml}$ against clinical isolates. The reduction in average $\mathrm{MIC}$ of $\mathrm{M}+\mathrm{R}$ in $\mathrm{M}+\mathrm{R}+\mathrm{Q}$ combination from $367.40 \pm 15.71$ to $148.31 \pm 19.59 \mu \mathrm{g} / \mathrm{ml}$ with IMP found greater than the rest of antibiotics against clinical isolates. While a decrease in average MIC of quercetin in $\mathrm{M}+\mathrm{R}+\mathrm{Q}$ combination, from $164.44 \pm 17.11 \mu \mathrm{g} / \mathrm{ml}$ to $65.94 \pm 16.9 \mu \mathrm{g} / \mathrm{ml}$ with CET was more than any other test 
Table 6 Exact MICs $(\mu \mathrm{g} / \mathrm{ml})$ of flavonoid/(s) against S. aureus (ATCC 43300) and clinical isolates of MRSA

\begin{tabular}{llll}
\hline & $(\mathbf{M}+\mathbf{R})^{\boldsymbol{*}}$ & $\mathbf{Q}$ & $(\mathbf{M}+\mathbf{R})^{\boldsymbol{\star}}+\mathbf{Q}$ \\
\hline S. aureus (ATCC 43300) & 400 & 260 & $(280)^{\boldsymbol{\star}}+140$ \\
Clinical Isolates & $427.40^{\mathrm{a}} \pm 14.40$ & $279.00^{\mathrm{a}} \pm 14.65$ & $(303.56)^{\boldsymbol{\star}} \pm 16.74+163.56^{\mathrm{a}} \pm 15.23$ \\
MIC Ranges & $400-440$ & $260-300$ & $\mathrm{M}+\mathrm{R}=280-340$ \\
& & & $\mathrm{Q}=140-200$ \\
\hline
\end{tabular}

* MIC's of M \& R are same in combination.

a $=$ Average value.

antibiotics against clinical isolates. However, ME showed least activity with this flavonoid combination. Important mention in this flavonoids combination is its enhancing effect on both AMP and AMO, while the rest of the flavonoids are either increasing AMO or AMP activity but not both.

MIC's of antibiotics alone as well as in combination with flavonoids (Table 8) were determined in order to prove that flavonoids decreased the MICs of antibiotics thereby increasing their activity against MRSA. In combination with flavonoids all antibiotics encountering resistance became sensitive while maximum susceptibility was conferred upon cell wall synthesis inhibitors. From Table 8 it is evident that MIC of AMO was $256 \mu \mathrm{g} / \mathrm{ml}$, which reduced significantly to $64 \mu \mathrm{g} / \mathrm{ml}$ in combination with $M+R$ against ATCC 43300. The MIC of AMO in combination with $\mathrm{M}+\mathrm{R}+\mathrm{Q}$ decrease more significantly than $\mathrm{M}+\mathrm{R}$ from $256 \mu \mathrm{g} / \mathrm{ml}$ to $8 \mu \mathrm{g} / \mathrm{ml}$. The observed average MIC of AMO against clinical isolates $(n=100)$ was $197.70 \pm 64.02 \mu \mathrm{g} / \mathrm{ml}$ that became $49.43 \pm 16.03 \mu \mathrm{g} / \mathrm{ml}$ when it was combined with $\mathrm{M}+\mathrm{R}$; and it reduced further to $6.00 \pm 2.13 \mu \mathrm{g} / \mathrm{ml}$ when used with $\mathrm{M}+\mathrm{R}+\mathrm{Q}$. MIC of AMP was $128 \mu \mathrm{g} / \mathrm{ml}$ against ATCC 43300 and its average MIC value against clinical isolates was $162.85 \pm 68.05 \mu \mathrm{g} / \mathrm{ml}$. However, no effect was observed in case of AMP when it was combined with $M+R$. In combination with $Q$, MIC of AMP dropped significantly from $128 \mu \mathrm{g} / \mathrm{ml}$ to $16 \mu \mathrm{g} / \mathrm{ml}$. The highest increase in activity was observed when AMP was used in combination with $\mathrm{M}+\mathrm{R}+\mathrm{Q}$, with MIC dropping from $128 \mu \mathrm{g} / \mathrm{ml}$ to $4 \mu \mathrm{g} / \mathrm{ml}$ against ATCC 43300 while its average MIC against clinical isolates $(\mathrm{n}=100)$ reduced from $162.85 \pm 68.05 \mu \mathrm{g} / \mathrm{ml}$ to $5.09 \pm 2.13 \mu \mathrm{g} / \mathrm{ml}$.

Table 7 Exact MICs $(\mu \mathrm{g} / \mathrm{ml}$ ) of flavonoid/(s) with antibiotics against S. aureus (ATCC 43300) and clinical isolates of MRSA

\begin{tabular}{|c|c|c|c|}
\hline & With $(M+R)^{*}$ & With Q & With $(M+R)^{*}+Q$ \\
\hline AMOt & 340 & 260 & $(140)^{2}+80$ \\
\hline $\mathrm{AMO}^{*}$ & $367.40 \pm 15.71$ & $279.00^{a} \pm 14.65$ & $\left(163.56^{a}\right)^{a} \pm 16.75+103.56^{a} \pm(15.99)$ \\
\hline MIC range* & $340-380$ & $260-320$ & $M+R=140-200 ; Q=80-140$ \\
\hline AMPt & 400 & 160 & $(160)^{*}+80$ \\
\hline AMP* & $427.40^{\mathrm{a}} \pm 14.40$ & $178.80^{\mathrm{a}} \pm 14.25$ & $\left(186.56^{a}\right)^{a} \pm 15.80+112.37^{a} \pm 16.42$ \\
\hline MIC range* & $400-440$ & $160-200$ & $M+R=160-220 ; Q=80-140$ \\
\hline CEPH† & 340 & 160 & $(140)^{\star}+60$ \\
\hline $\mathrm{CEPH}^{*}$ & $367.40 \pm 15.71$ & $178.80^{\mathrm{a}} \pm 14.25$ & $\left(163.56^{a}\right)^{a} \pm 16.52+83.56^{a} \pm 15.02$ \\
\hline MIC range* & $340-380$ & $160-200$ & $M+R=140-200 ; Q=60-120$ \\
\hline CET + & 320 & 140 & $(140)^{\star}+40$ \\
\hline $\mathrm{CET}^{*}$ & $347.40 \pm 12.92$ & $158.60^{\mathrm{a}} \pm 15.11$ & $\left(162.94^{a}\right)^{\star} \pm 16.98+65.94^{a} \pm 16.9$ \\
\hline MIC range* & $320-360$ & $140-180$ & $M+R=140-180 ; Q=40-100$ \\
\hline IMP† & 300 & 120 & $(120)^{\star}+40$ \\
\hline IMP* & $327.80^{\mathrm{a}} \pm 14.85$ & $138.80^{\mathrm{a}} \pm 14.99$ & $\left(148.31^{a}\right)^{a} \pm 19.59+66.56^{a} \pm 16.50$ \\
\hline MIC range* & $300-340$ & $120-160$ & $M+R=120-180 ; Q=40-100$ \\
\hline ME† & 360 & 180 & $180+80$ \\
\hline$M E^{*}$ & $387.40 \pm 15.78$ & $196.70^{a} \pm 12.75$ & $\left(208.51^{a}\right)^{a} \pm 19.98+88.51^{a} \pm 19.80$ \\
\hline MIC range* & $360-400$ & $180-220$ & $M+R=180-240 ; Q=80-160$ \\
\hline
\end{tabular}

*MIC of $M \& R$ is same.

a = Average value.

*against MRSA clinical isolates $(n=100)$.

† against S. aureus (ATCC 43300). 
Table 8 Exact MICs $(\mu \mathrm{g} / \mathrm{ml})$ of antibiotics with flavonoid/(s) against S. aureus (ATCC 43300) and clinical isolates of MRSA

\begin{tabular}{|c|c|c|c|c|}
\hline & Antibiotic alone & With $M+R$ & With Q & With $M+R+Q$ \\
\hline AMO † & 256 & $64^{*}$ & 256 & 8 \\
\hline $\mathrm{AMO} *$ & $197.70^{a} \pm 64.02$ & $49.43^{a} \pm 16.03$ & $197.70^{\mathrm{a}} \pm 64.02$ & $6.00^{a} \pm 2.13$ \\
\hline MIC range* & $128-256$ & $32-64$ & $128-256$ & $2-8$ \\
\hline AMP † & 128 & 128 & 16 & 4 \\
\hline $\mathrm{AMP} *$ & $162.85^{\mathrm{a}} \pm 68.05$ & $162.85^{\mathrm{a}} \pm 68.05$ & $20.36^{\mathrm{a}} \pm 8.51$ & $5.09^{\mathrm{a}} \pm 2.13$ \\
\hline MIC range* & $64-256$ & $64-256$ & $8-32$ & $2-8$ \\
\hline CEPH† & 256 & 64 & 32 & 8 \\
\hline $\mathrm{CEPH}^{*}$ & $200.96^{\mathrm{a}} \pm 63.69$ & $50.38^{a} \pm 17.92$ & $25.12^{\mathrm{a}} \pm 7.92$ & $6.28^{\mathrm{a}} \pm 1.99$ \\
\hline MIC range* & $128-256$ & $32-64$ & $16-32$ & $4-8$ \\
\hline CET + & 64 & 16 & 8 & 2 \\
\hline $\mathrm{CET}^{*}$ & $67.52^{a} \pm 30.48$ & $27.09^{a} \pm 16.94$ & $8.44^{a} \pm 3.81$ & $2.11^{\mathrm{a}} \pm 0.95$ \\
\hline MIC range* & $32-128$ & $16-64$ & $4-16$ & $1-4$ \\
\hline IMP † & 32 & 8 & 4 & 1 \\
\hline IMP* & $130.88^{a} \pm 84.02$ & $32.72^{a} \pm 16.15$ & $19.88^{a} \pm 10.51$ & $4.97^{\mathrm{a}} \pm 2.63$ \\
\hline MIC range* & $32-256$ & $8-64$ & $4-32$ & $1-8$ \\
\hline ME † & 64 & 16 & 8 & 2 \\
\hline$M E^{*}$ & $135.68^{a} \pm 54.03$ & $33.92^{\mathrm{a}} \pm 13.51$ & $16.96^{\mathrm{a}} \pm 6.75$ & $4.24^{a} \pm 1.69$ \\
\hline MIC range* & $64-256$ & $16-64$ & $8-32$ & $2-8$ \\
\hline
\end{tabular}

*MIC of $M \& R$ is same.

$a^{a}=$ Average value.

*against MRSA clinical isolates $(n=100)$.

† against S. aureus (ATCC 43300).

\section{Fractional inhibitory concentration (FIC) \& Fractional inhibitory concentration index (FICl)}

In order to term effect of antibiotics used in combination with flavonoids as synergistic or additive FICI's were evaluated. The results (Table 9) showed an additive response in case of quercetin and morin + rutin in combination with test antibiotics such as amoxicillin, Ampicillin, ceftriaxone, cephradine, imipenem and methicillin. However, synergism was indicated when these antibiotics were used in conjunction with $M+R+Q$.

\section{Detection of cytoplasm membrane damage}

The potassium leakage was measured for test bacteria with flavonoids \& antibiotics alone and flavonoids-antibiotics in combination. From the data (Tables 10 and 11) it is apparent that $\mathrm{K}+$ leakage from flavonoid-antibiotic combination was greater than the flavonoids and antibiotics alone. All antibiotics and flavonoids induced release of $\mathrm{K}+$ confirming damage they inflicted to bacterial cell membrane. $\mathrm{K}+$ measured in case of AMO was 25.7 ppm for ATCC 43300 whilst for clinical isolates average $\mathrm{K}+$ release was $25.79 \pm$ $0.16 \mathrm{ppm}$. AMO's $\mathrm{K}+$ release in combination with $\mathrm{M}+\mathrm{R}$ was $32.3 \mathrm{ppm}$ and $32.40 \pm 0.13 \mathrm{ppm}$ for ATCC 43300 and clinical isolates, respectively. Highest leakage of potassium was observed for IMP that was $26.6 \mathrm{ppm}$ against ATCC 43300 and $26.79 \pm 0.14 \mathrm{ppm}$ for clinical isolates. The $\mathrm{K}+$ leakage was further increased when IMP was used with flavonoids i.e. $36.6 \mathrm{ppm}$ with $\mathrm{M}+\mathrm{R}, 39.2 \mathrm{ppm}$ with $\mathrm{Q}$ and $44.7 \mathrm{ppm}$ with $\mathrm{M}+\mathrm{R}+\mathrm{Q}$ against ATCC 43300. The effect became even more when $M+R+Q$ was combined with antibiotics (amoxicillin, Ampicillin, ceftriaxone, cephradine, imipenem and methicillin), since $K+$ level from $M+R+Q$ was 32.7 ppm in case of ATCC 43300 while in case of isolates average value of $\mathrm{K}+$ leakage was $32.29 \pm 0.13 \mathrm{ppm}$. K+ leakage for $A M O$ in combination with $M+R$ was $32.3 \mathrm{ppm}$, which increased to $41 \mathrm{ppm}$ with $\mathrm{M}+\mathrm{R}+\mathrm{Q}$ in case of ATCC 43300. Similar trend was observed in case of other antibiotics.

\section{Discussion}

MRSA is now commonly isolated bug from nosocomial infections and has potential to lead to fatalities. With passage of time MRSA has also shown resistance to other antibiotics as well such as tetracyclines, erythromycin and genatmacin [17]. As a result of MDR (multidrug resistance) the only choice left is vancomycin, which is also experiencing resistance and reports of emergence of vancomycin intermediate S.aureus (VISA) and vancomycin resistant $S$. aureus (VRSA) are there [17]. Therefore it is the need of day to analyze MRSA and find new treatment modalities.

Morin and rutin alone have no antibacterial activity but together they were active against $S$. aureus ATCC 25923 and E. coli ATCC 25922 [18]. Moreover, rutin has been reported to enhance antibacterial activity of several 
Table 9 Fractional Inhibitory Concentration indices (FICI) of flavonoid/(s) and antibiotics against S. aureus (ATCC 43300) and clinical isolates of MRSA

\begin{tabular}{llll}
\hline $\begin{array}{l}\text { Flavonoid/(s) } \\
\text { antibiotics }\end{array}$ & FICl & & \\
\cline { 2 - 4 } & $\begin{array}{l}\text { S. aureus } \\
\text { (ATCC 43300) }\end{array}$ & $\begin{array}{l}\text { MRSA clinical } \\
\text { isolates ( } \mathbf{n} \text { 100) }\end{array}$ & Inference \\
\hline$M+R+$ AMO & 0.9 & 0.9 & Additive \\
$M+R+C E P H$ & 0.9 & 0.95 & Additive \\
$M+R+C E T$ & 0.8 & 0.94 & Additive \\
$M+R+$ IMP & 0.84 & 0.85 & Additive \\
$M+R+M E$ & 0.95 & 0.97 & Additive \\
$Q+A M P$ & 0.74 & 0.77 & Additive \\
$Q+C E P H$ & 0.74 & 0.77 & Additive \\
$Q+C E T$ & 0.66 & 0.69 & Additive \\
$Q+I M P$ & 0.66 & 0.69 & Additive \\
$Q+M E$ & 0.82 & 0.83 & Additive \\
$M+R+Q+A M O$ & 0.59 & 0.66 & Additive \\
$M+R+Q+A M P$ & 0.59 & 0.68 & Additive \\
$M+R+Q+C E P H$ & 0.46 & 0.50 & Synergism \\
$M+R+Q+C E T$ & 0.31 & 0.44 & Synergism \\
$M+R+Q+I M P$ & 0.32 & 0.45 & Synergism \\
$M+R+Q+M E$ & 0.45 & 0.5 & Synergism \\
\hline
\end{tabular}

compounds such as aminopenicillanic acid [19] and other flavonoids such as morin and rutin against Salmonella enteritidis and Bacillus cereus [15].Morin was found active E. coli ATCC 25922, P. aeruginosa ATCC 27853 and S. aureus ATCC 29213 and respective clinical isolates [20].

Quercetin activity has also been reported to increase with oxacillin, vancomycin, gentamycin, and erythromycin [21]. Quercetin is also found to increase the activity of rifampicin and fusidic acid against MRSA 43300 and clinical isolates [22]. Quercetin alone has been found active against $S$. aureus and $K$. pneumoniae [23]. It has also been found to be potentiating effects of antibiotics such as rifampicin, fusidic acid and rifampicin against MRSA and MSSA [24]. Quercetin alone and in combination with gentamycin, levolfloxacin and sulphadiazine was found to be synergistic since MIC of qurecetin and test antibiotics decreased four folds when they were combined with each other [14]. Quercetin's MIC of

Table 10 Potassium leakage (ppm) by flavonoid/(s) against S. aureus (ATCC 43300) and clinical isolates of MRSA

\begin{tabular}{lllll}
\hline & Control & $\mathbf{Q}$ & $\mathbf{M}+\mathbf{R}$ & $(\mathbf{M}+\mathbf{R})^{\mathbf{*}+\mathbf{Q}}$ \\
\hline $\begin{array}{l}\text { S. aureus } \\
\text { (ATCC 43300) }\end{array}$ & 10.2 & 28.4 & 26.4 & 32.7 \\
Clinical Isolates & $10.19 \pm 0.18$ & $28.49 \pm 0.14$ & $26.49 \pm 0.12$ & $32.29 \pm 0.13$
\end{tabular}

*MIC of M \& R is same.
$260 \mu \mathrm{g} / \mathrm{ml}$ is comparable to previous report of $256 \mu \mathrm{g} / \mathrm{ml}$ against MRSA [7]. It is evident from data (Table 4) that among resistant antibiotics on which quercetin had enhancing effect; CET was most responsive as increase in the activity was greater than other antibiotics i.e. zones of inhibition enhanced from 0 to $20.5 \pm 0.5 \mathrm{~mm}$ in ATCC 43300. While in case of clinical isolates $(n=100)$ the average zone of inhibition increased from 0 to $20.83 \pm$ $0.45 \mathrm{~mm}$. Those antibiotics including ERY, VAN and IMP which were sensitive against ATCC 43300, among them only IMP antibacterial activity increased as its inhibitory zone rose from $16 \pm 0.90 \mathrm{~mm}$ to $22 \pm 1.10 \mathrm{~mm}$ in combination with quercetin. The S-T remained resistant even in combination with quercetin. The results are consistent with different reports in which it was used in combination with antibiotics. Results can also be compared to the results reported by Goyal et al., [25] where morin was used in combination with quercetin against $S$. aureus, Salmonella typhi, E. coli and B. subtilis. It was found that as a result of using them in combination MICs of these flavonoids had significantly decreased e.g. MIC's of morin and quercetin against $S$. aureus were $64 \mu \mathrm{g} / \mathrm{ml}$ and $32 \mu \mathrm{g} / \mathrm{ml}$. But when these flavonoids were combined MIC became $16 \mu \mathrm{g} / \mathrm{ml}$ [15]. Morin and rutin alone had no activity against MRSA but in combination showed antibacterial activity against said bacteria. In similar studies flavonoids combinations and their metallo-combinations show activity against various microbes [26,27]. Morin alone has been found to be active against Salmonella enteritidis with MIC of $150 \mu \mathrm{g} / \mathrm{ml}$ and B. cereus with MIC of $300 \mu \mathrm{g} / \mathrm{ml}$. MICs were further reduced when morin was combined with rutin, i.e. MIC of morin with rutin lessened to $50 \mu \mathrm{g} / \mathrm{ml}$ against $S$. enteritidis, while in case of B. cereus morin's MIC reduced to $100 \mu \mathrm{g} / \mathrm{ml}$ [15]. Morin also showed inhibitory activity against S. typhi, E. coli, B. subtilis, and S. aureus with MIC's of $128 \mu \mathrm{g} / \mathrm{ml}, 128 \mu \mathrm{g} / \mathrm{ml}, 64 \mu \mathrm{g} / \mathrm{ml}$ and $64 \mu \mathrm{g} / \mathrm{ml}$, respectively [25]. Morin when tested against P. aeruginosa (ATCC 9027), S. epidermidis (ATCC 12228), B. subtilis (ATCC 9372 \& 6633) and E. coli (ATCC 8739 \& 11775) inhibited the growth of all these bacteria [28]. In another study the activity of morin and its complexes with Gadolinium and Lutetium were tested against different bacterial strains such as E. coli, K. pneumoniae, S. aureus; results revealed morin complexes with $\mathrm{Lu}$, and $\mathrm{Gd}$, to be more active than alone, thus suggesting potentiation by these elements [29]. As evident from literature, morin antibacterial activities enhance in combination with rutin, therefore, this combination was tested against MRSA and also with conventional antibiotics that are experiencing resistance from this bug.

In present study combination of three flavonoids enhanced their anti staphylococcal potential which is evident from the MIC data. The MIC of $\mathrm{M}+\mathrm{R}$ decreased from $400+400 \mu \mathrm{g} / \mathrm{ml}$ to $280+280 \mu \mathrm{g} / \mathrm{ml}$ and that of $\mathrm{Q}$ 


\begin{tabular}{|c|c|c|c|c|}
\hline Test antibiotics & Antibiotic alone & Antibiotic $+M+R$ & Antibiotic $+Q$ & Antibiotic $+M+R+Q$ \\
\hline AMO † & 25.7 & 32.3 & NT & 41 \\
\hline $\mathrm{AMO} *$ & $25.79 \pm 0.16$ & $32.40 \pm 0.13$ & NT & $41.09 \pm 0.11$ \\
\hline AMP † & 25.6 & NT & 34.4 & 39.6 \\
\hline AMP * & $25.69 \pm 0.13$ & NT & $34.49 \pm 0.14$ & $39.83 \pm 0.12$ \\
\hline CEPH† & 25.70 & 33.20 & 35.2 & 40 \\
\hline $\mathrm{CEPH}^{*}$ & $25.89 \pm 0.14$ & $33.30 \pm 0.14$ & $35.39 \pm 0.14$ & $40.10 \pm 0.10$ \\
\hline CET + & 25.9 & 34.60 & 37.5 & 42.6 \\
\hline $\mathrm{CET}^{*}$ & $25.96 \pm 0.10$ & $34.69 \pm 0.15$ & $37.59 \pm 0.10$ & $42.69 \pm 0.13$ \\
\hline IMP † & 26.6 & 36.6 & 39.2 & 44.7 \\
\hline IMP* & $26.79 \pm 0.14$ & $36.79 \pm 0.15$ & $39.26 \pm 0.14$ & $45.89 \pm 0.14$ \\
\hline ME † & 25.1 & 31.4 & 34.3 & 39.2 \\
\hline$M E^{*}$ & $25.29 \pm 0.12$ & $31.52 \pm 0.13$ & $34.43 \pm 0.11$ & $39.33 \pm 0.12$ \\
\hline
\end{tabular}

*against MRSA clinical isolates $(n=100)$.

† against S. aureus (ATCC 43300).

NT $=$ Not tested.

reduced from $260 \mu \mathrm{g} / \mathrm{ml}$ to $140 \mu \mathrm{g} / \mathrm{ml}$ against MRSA 43300. In case of clinical isolates the $M+R$ average MICs reduced from $427.40 \pm 14.40 \mu \mathrm{g} / \mathrm{ml}$ to $303.56 \pm 16.74 \mu \mathrm{g} / \mathrm{ml}$. While the average MIC of Q against the clinical isolates decreased from $279.00 \pm 14.65 \mu \mathrm{g} / \mathrm{ml}$ to $163.56 \pm 15.23 \mu \mathrm{g} / \mathrm{ml}$. It is in confirmation to the studies in which rutin, morin and quercetin gave a synergistic response against $S$. aureu, E.coli and Enterobacter aerogenes [7,19,30].

In present study MIC of CEPH was $256 \mu \mathrm{g} / \mathrm{ml}$ against ATCC 43300 and its average MIC was $200.96 \pm$ $63.69 \mu \mathrm{g} / \mathrm{ml}$ against clinical isolates. The MIC of CEPH in combination with $\mathrm{M}+\mathrm{R}$ decreased significantly to $64 \mu \mathrm{g} / \mathrm{ml}$ against the ATCC 43300 and its average MIC against clinical isolates decreased to $50.38 \pm 17.92 \mu \mathrm{g} / \mathrm{ml}$. The MIC of CET was $64 \mu \mathrm{g} / \mathrm{ml}$ against ATCC 43300 that reduced to $16 \mu \mathrm{g} / \mathrm{ml}$ when it was combined with $\mathrm{M}+\mathrm{R}$. While in case of clinical isolates average MIC of $67.52 \pm 30.48 \mu \mathrm{g} / \mathrm{ml}$ for CET was observed that reduced to $27.09 \pm 16.94 \mu \mathrm{g} / \mathrm{ml}$ when it was combined with $M+R$. Similarly, CET in combination with $\mathrm{Q}$ and $\mathrm{Q}+\mathrm{M}+\mathrm{R}$, against ATCC $43300 \mathrm{MIC}$ of $64 \mu \mathrm{g} / \mathrm{ml}$ dropped to $32 \mu \mathrm{g} / \mathrm{ml}$ and $8 \mu \mathrm{g} / \mathrm{ml}$ respectively that are in confirmation to earlier reports [31,32].

The MIC of imipenem was $32 \mu \mathrm{g} / \mathrm{ml}$ against ATCC 43300 that reduced to $8 \mu \mathrm{g} / \mathrm{ml}$ when IMP was combined with $M+R$. While its average MIC against clinical isolates was $130.88 \pm 84.02 \mu \mathrm{g} / \mathrm{ml}$. In combination with $M+R$ average MIC reduced to $32.82 \pm 16.15 \mu \mathrm{g} / \mathrm{ml}$. The MIC range $(32-256 \mu \mathrm{g} / \mathrm{ml})$ of IMP against MRSA clinical isolates found almost similar to that reported earlier [33]. In this study IMP tested alone and in combination with catechins flavonoids (extracted from green tea leaves) against MRSA clinical samples and standard ATCC 25923. The MIC range found in this study was $16-256 \mu \mathrm{g} / \mathrm{ml}$. In present study reduction in the imipenem's MIC along with $Q+M+R$ was found greater than the other flavonoids. The MIC observed against ATCC 43300 was $1 \mu \mathrm{g} / \mathrm{ml}$ and against the clinical isolates it's MIC range reduced from $32-256 \mu \mathrm{g} / \mathrm{ml}$ to $1-8 \mu \mathrm{g} / \mathrm{ml}$.

MIC of ME was $64 \mu \mathrm{g} / \mathrm{ml}$ against ATCC 43300 that reduced to $16 \mu \mathrm{g} / \mathrm{ml}$ when it was combined with $M+R$, this trend was also observed in case of clinical isolates where average MIC decreased form $135.68 \pm 54.03 \mu \mathrm{g} / \mathrm{ml}$ to $33.92 \pm 13.51 \mu \mathrm{g} / \mathrm{ml}$. Effective concentrations of $\mathrm{ME}$ were further reduced against the test bacteria when it was combined with $\mathrm{M}+\mathrm{R}+\mathrm{Q}$ with MICs of $2 \mu \mathrm{g} / \mathrm{ml}$ and $4.24 \pm 1.69 \mu \mathrm{g} / \mathrm{ml}$ for ATCC 43300 and clinical isolates respectively.

The results also revealed that combined effects of morin + rutin and quercetin in combination with the antibiotics were additive $(\mathrm{FICI}<1)$. However, relationships between quercetin + morin + rutin and CEPH, IMP, CET and $\mathrm{ME}$ were synergistic $(\mathrm{FICI} \leq 0.5)$. While $\mathrm{Q}+\mathrm{M}+\mathrm{R}$ with AMP and AMO showed additive effect $(\mathrm{FICI}<1)$. These results are in in conformity with earlier findings where quercetin was found to be synergistic with minocycline, fusidic acid and rifampicin [24].

Various compounds e.g. phenolics, have been known for their ability to effect cytoplasmic membrane permeability consequently resulting in leakage of cellular constituents like nucleic acids, proteins and inorganic ions such as phosphate and potassium [34]. Results of this study suggest potassium leakage when flavonoids were used alone, in combinations and with test antibiotics. Potassium leakage data for $\mathrm{Q}(28.4 \mathrm{ppm}), \mathrm{M}+\mathrm{R}(26.4 \mathrm{ppm})$, and $\mathrm{M}+\mathrm{R}+\mathrm{Q}$ (32.7 $\mathrm{ppm}$ ) against ATCC 43300 suggest increase in extracellular $\mathrm{K}+$ in comparison to control (10.2 ppm). The highest $\mathrm{K}+$ release was observed in 
case of antibiotics in combination with $\mathrm{M}+\mathrm{R}+\mathrm{Q}$. The results can be paralleled to that of galangin, a flavonol that target cytoplasmic membrane of $S$. aureus and cause potassium leakage [6].

Since the test concentrations used for antibiotics were their MICs, therefore, $\mathrm{K}+$ release was also observed in the inoculums of test bacteria to which antibiotics were added. The $\mathrm{K}+$ release was increased when flavonoids were used in conjunction to test antibiotics and highest release was found in case of CET + M + R (34.60 ppm \& $34.69 \pm 0.15 \mathrm{ppm}), \mathrm{CET}+\mathrm{Q}(37.5 \mathrm{ppm} \& 37.59 \pm 0.10 \mathrm{ppm})$, $\mathrm{CET}+\mathrm{M}+\mathrm{R}+\mathrm{Q}(42.6 \mathrm{ppm} \& 42.69 \pm 0.13 \mathrm{ppm})$ against ATCC 43300 and clinical isolates, respectively. Similarly, $\mathrm{IMP}+\mathrm{M}+\mathrm{R}(36.6 \mathrm{ppm} \& 36.79 \pm 0.15 \mathrm{ppm}), \mathrm{IMP}+\mathrm{Q}$ (39.2 ppm \& $39.26 \pm 0.14 \mathrm{ppm}), \mathrm{IMP}+\mathrm{M}+\mathrm{R}+\mathrm{Q}(44.7 \mathrm{ppm}$ \& $42.89 \pm 0.14 \mathrm{ppm})$ against ATCC 43300 and clinical isolates, respectively. Since both CET and IMP are bacterial cell wall inhibitors, therefore, it can be hypothesized that wall damage was implicated by test antibiotics while cytoplasmic membrane injury was inflicted by flavonoids; with greater damage observed with combination of flavonoids.

The present data suggests that antibiotics activity was increased in combination with flavonoids. The flavonoids used such as morin, rutin, and quercetin may also target the cell wall of MRSA as evidenced from potassium leakage data. Thus, combination of flavonoids with antibiotics can be considered for therapeutic application in case of microbes expressing resistance after safety evaluations.

The present research was limited to in-vitro studies only because of non-availability of animal models facilities, which remained the major limitation of these studies. Since the findings are promising, therefore, they can be extended to in-vivo stage.

\section{Conclusions}

From the antibiotic sensitivity assays it is evident that morin and rutin in combination were effective against MRSA ATCC 43300 and its clinical isolates, while quercetin alone found active against test bacteria. The activity of flavonoids was further enhanced against ATCC 43300 and clinical isolates, when rutin, morin and quercetin were used in combination. Test bacteria responded to ampicillin, amoxicillin, cephradine, methicillin and ceftriaxone when these antibiotics were mixed with flavonoids. Similarly, imipenem activity was further increased against test MRSA strains when combined with flavonoids. Through MIC assays it was observed that both the flavonoids and antibiotics supplemented each other effects. FICI results indicated an additive relationship between the flavonoids and the antibiotics. While a synergistic effect was also observed in $\mathrm{M}+\mathrm{R}+\mathrm{Q}$-antibiotics combinations. The cell wall synthesis inhibitors showed positive activity in conjunction to test flavonoids while activity of antibiotics affecting nucleic acid got blunted. Measurement of potassium loss suggested cytoplasmic membrane damage in conjunction with cell wall damage can be assumed to be the mechanism of action of these flavonoids antibiotic combinations. The sum of the substance of results was that the activity of both flavonoids and antibiotics found to increase when they were combined with each other.

\section{Competing interests}

The authors declare that they have no competing interests.

\section{Authors' contributions}

MUA carried out the experimentation and drafting of manuscript. MK contributed with conception and design of study, interpretation of data, and manuscript preparation. BK and JK participated in data analysis and interpretation. All authors read and approved the final manuscript.

\section{Acknowledgements}

Authors duly acknowledge the facilitation of Dr. Javed Ali, Mr. Zia-ur-Rehman and the staff of Microbiology section, PCSIR, Peshawar, and Mr. Abdur Razzaq from Sarhad University of Science \& IT in in carrying out some experimentation.

\section{Author details}

${ }^{1}$ Department of Microbiology, Kohat University of Science and Technology, Kohat, KP, Pakistan. ${ }^{2}$ Department of Pharmacy, Shaheed Benazir Bhutto University, Sheringal, Dir Upper, KP, Pakistan.

Received: 2 September 2014 Accepted: 21 February 2015

Published online: 12 March 2015

\section{References}

1. Mazid M, Khan TA, Mohammad F. Role of secondary metabolites in defense mechanisms of plants. Biol Med. 2011;3(2):232-49.

2. Bandi AK, Lee DU. Secondary metabolites of plants from the genus Cipadessa: chemistry and biological activity. Chem Biodivers. 2012;9(8):1403-21.

3. Wang YF, Ni ZY, Dong M, Cong B, Shi QW, Gu YC, et al. Secondary metabolites of plants from the genus Saussurea chemistry and biological activity. Chem Biodivers. 2010;7(11):2623-59.

4. Cushnie TP, Lamb AJ. Detection of galangin-induced cytoplasmic membrane damage in Staphylococcus aureus by measuring potassium loss. J Ehanopharmacol. 2005;101:243-8.

5. Bylka W, Matlawska I, Pilewski NA. Natural flavonoids as antimicrobial agents. J Am Nutraceutical Assoc. 2004;7(2):24-31.

6. Cushnie TP, Lamb AJ. Antimicrobial activity of flavonoids. Int J of Antimicrob Agents. 2005;26:343-56.

7. Xu HX, Lee SF. Activity of plant flavonoids against antibiotic-resistant bacteria. Phytother Res. 2001;15:39-43.

8. Shibata H, Kondo K, Katsuyama R, Kawazoe K, Sato Y, Murakami K, et al. Alkyl gallates, intensifiers of beta lactam susceptibility in methicillin-resistant Staphylococcus aureus. Antimicrob Agents Chemother. 2005;49:549-55.

9. Mutao CA, Jarnigan JA, Ostrowsky BE, Richet HM, Jarvis WR, Boyce JM, et al. SHEA guidelines for preventive Nosocomial transmission of multiresistant strains of Staphlococcus aureus and Enterococcus. Infect Control Hosp Epidemiol. 2004;24:362-8.

10. Idrees F, Jabeen K, Khan MS, Zafar A. Antimicrobial resistance profile of Methicillin Resistant Staphylococcal Aureus from skin and soft tissue isolates. J Pak Assoc. 2009;59(5):266-9.

11. Engelkirk PG, Duben-Engelkirk JL. Laboratory Diagnosis of Infectious Diseases, Essential of Diagnostic Microbiology. In: Gram positive Cocci. Philadelphia PA: Lippincott Williams \& Wilkins; 2008. p. 215-9.

12. Bannerman TL. Staphylococcus, Micrococcus, and other catalase-positive cocci that grow aerobically. In: Murray PR, Baron EJ, Jorgensen JH, Pfaller MA, Yolken RH, editors. Manual of clinical microbiology. 8th ed. Washington, D.C: American Society for Microbiology Press; 2003.

13. Ergene A, Guler P, Tan S, Mirici S, Hamzaoglu E, Duran A. Antimicrobial and antifungal activity of Heracleum sphondylium subsp. artivinense. Afr J Biotechnol. 2006;5(11):1087-9. 
14. Sakharkar MK, Jayaraman P, Soe WM, Chow VTK, Sing LC, Sakharkar K. In vitro combinations of antibiotics and phytochemicals against Pseudomonas aeruginosa. J Microbiol Immunol Infect. 2009;42:364-70.

15. Arima $\mathrm{H}$, Ashida H, Danno G. Rutin-enhanced antibacterial activities of flavonoids against Bacillus cereus and Salmonella enteritidis. Biosci Biotechno Biochem. 2002;66(5):1009-14.

16. European Committee on Antimicrobial Susceptibility Testing. Terminology relating to methods for the determination of susceptibility of bacteria to antimicrobial agents. EUCAST Definitive Document E. Def 1.2. Clini Microbiol Infect. 2000;6:503-8.

17. Khan A, Faisal S, Hasnain S. The continuing threat of methicillin-resistant staphylococcus aureus- past present future. J Scientific Res. 2010;40:37-45.

18. Alvarez MDLA, Debattista NB, Pappano NB. Synergism of flavonoids with bacteriostatic action against Staphylococcus aureus ATCC 25923 and Escherichia coli ATCC 25 922. Biocell. 2006:30(1):39-42.

19. Lupaşcus D, Tuchiluş C, Profire L. Physico - chemical and antimicrobial properties of novel rutin derivatives with 6-aminopenicillanic acid. Farmacia. 2010;56(5):501-6.

20. Woènicka E, Kuèniar A, Nowak D, Nykiel E, Kopacz M, Gruszecka J, et al. Comparative study on the antibacterial activity of some flavonoids and their sulfonic derivatives. Pol Soc Pharm Drug Res. 2013;70(3):567-71.

21. Hirai I, Okuno M, Katsuma R, Arita N, Tachibana M, Yamamoto Y. Characterisation of anti-Staphylococcus aureus activity of Quercetin. Int J Food Sci Technol. 2010;45:1250-4

22. Kyaw BM, Arora S, Win KN, Daniel LCS. Prevention of emergence of fusidic acid and rifampicin resistance in Staphylococcus aureus using phytochemicals. Afr J Microbiol Res. 2011;5(22):3684-92.

23. Xing ZC, Meng W, Yuan J, Moon S, JeongY KyuKang I. In vitro assessment of antibacterial activity and cytocompatibility of quercetin-containing PLGA nanofibrous scaffolds for tissue engineering. J Nanomaterials. 2012;2012:1-7.

24. Kyaw BM, Arora A, Lim CS. Bactericidal antibiotic-phytochemical combinations against methicillin resistant Staphylococcus Aureus. Braz J of Microbiol. 2012:43(3):938-45.

25. Goyal P, Aggarwal BK, Garg S. A study on combinatorial effects of various flavonoids for their antibacterial potential against clinically significant bacterial species. Hacettepe J Biol Chem. 2010;38(4):255-8.

26. Hendra R, Ahmad S, Sukari A, Shukor MY, Oskoueian E. Flavonoid analysis and antimicrobial activity of various parts of Phaleria macrocarpa (Scheff.) Boerl fruit. Int J Mol Sci. 2011;12:3422-31.

27. Pereira AC, Oliveira DF, Geraldo H, Silva GH, Figueiredo HCP, Cavalheiro AJ. Identification of the antimicrobial substances produced by Solanum palinacanthum (Solanaceae). Ann Braz Academy Sci. 2008;80:427-32.

28. Rauha JP, Remes S, Heinonen M, Hopia A, Kaahkonen M, Kujala T, et al Antimicrobial effects of finnish plant extracts containing flavonoids and other phenolic compounds. Int J Food Microbiol. 2003;56:3-12.

29. Kopacz M, Woènicka L, Gruszecka J. Antibacterial activity of morin and its complexes with La(III), Gd(III) AND Lu(III) IONS. Pol Pharm Society. 2005;62(1):65-7.

30. Alvarez MA, Debattista NB, Pappano NB. Antimicrobial activity and synergism of some substituted flavonoids. Folia Microbioligica. 2008;53(1):23-8.

31. Jones RN, Farrell DJ, Mendes RE, Sader HS. Comparative ceftaroline activity tested against pathogens associated with community-acquired pneumonia: results from an international surveillance study. J Antimicrob Chemother. 2011;66:69-80.

32. Odenholt I, Lowdin E, Cars O. In vitro pharmacodynamic studies of L-749345 in comparison with imipenem and Ceftriaxone against gram positive and gram negative bacteria. Antimicrob Agents Chemother. 1998:42(9):2365-70.

33. Aboulmagd E, Al-Mohammad HI, A-Badry S. Synergism and postantibiotic effect of green tree extract and imipenem against methicillin-resistant Staphylococcus sureus. Microbiol J. 2011;1(3):89-96.

34. Campos FM, Couto JA, Figueiredo AR, Tóth IV, Rangel AOSS, Hogg TA. Cell membrane damage induced by phenolic acids on wine lactic acid bacteria. Int J Microbiol. 2009;135(2):144-51.

\section{Submit your next manuscript to BioMed Central and take full advantage of:}

- Convenient online submission

- Thorough peer review

- No space constraints or color figure charges

- Immediate publication on acceptance

- Inclusion in PubMed, CAS, Scopus and Google Scholar

- Research which is freely available for redistribution

Submit your manuscript at www.biomedcentral.com/submit 